\title{
Descriptions and Classification of Cancer in the Classical Ayurvedic Texts
}

\author{
P Ram Manohar*
}

(Received 21 November 2014)

\begin{abstract}
The first accounts of cancer in the history of medicine can be seen in seven papyri from Egypt dating back to $1600 \mathrm{BC}$. The term 'cancer' was coined by Hippocrates (ca. $460 \mathrm{BC}-\mathrm{ca} .370 \mathrm{BC}$ ) in his corpus. Descriptions of diseases resembling cancer have also been codified in the classical Ayurvedic texts, which were composed few centuries before the Common Era. The discussion in the Suśruta Samhitā of the disease known as arbuda has striking resemblance to tumour forming cancers, with vivid clinical observations differentiating it from other growths. Suśruta also describes recurrence (adhyarbuda) and metastasis (dvirarbuda) while the Caraka Samhitā differentiates benign tumour (granthi) from malignant tumour ( $\operatorname{rrbuda}$ ) by the presence of a capsule (kośa). The classical texts of Ayurveda have also classified arbuda into many types. There is no direct evidence revealing the understanding of non-tumour forming cancers in the tradition of Ayurveda. On the other hand, there are also diseases other than arbuda whose descriptions resemble cancer. This suggests that there was no umbrella term for cancer that included all types of malignancies under one heading. There is indication that the ancient physicians may have understood the correlation between chronic inflammation and cancer as arbuda (malignant tumour) is considered to be an outcome of oedema and inflammation (sotha). Many herbs used in Ayurveda have been screened for activity against cancer and in-vitro and in-vivo studies have given promising leads. Ayurvedic physicians have also reported good outcomes when Ayurvedic treatments are administered as an adjuvant to chemotherapy and radiation for the management of cancer. There are also anecdotal reports of successful management of cancer with Ayurvedic treatment.
\end{abstract}

Key words: Arbuda, Ayurveda, Cancer, Granthi

\section{INTRODUCTION}

Descriptions of cancer can be seen from antiquity as early as 1600 BC in Egypt. The Ebers Papyrus, which is a 110 page scroll 20 metres in length is preserved at the library in the University of Leipzig, Germany and refers to tumours. Edwin Smith's Surgical Papyrus is perhaps the first record of breast cancer in human history.

The origin of the word cancer is credited to the Greek physician Hippocrates (460-370 BC), who is considered the "Father of Medicine." Hippocrates used the terms carcinos and carcinoma to describe non-ulcer forming and ulcer-forming tumours. In Greek, these words refer to a crab, most likely applied to the disease because the finger-like spreading projections from a cancer called to mind the shape of a crab. The Roman physician, Celsus (28-50 BC), later translated the Greek term into cancer, the Latin word for crab. Galen (130-200 AD), another Greek physician, used the word oncos (Greek for swelling) to describe tumours. Although the crab analogy of Hippocrates and Celsus is still used to describe malignant tumours, Galen's term is now used as a

\footnotetext{
* Director and CSO, AVP Research Foundation, 136/137, Trichy Road, Ramanathapuram, Coimbatore, Tamil Nadu, India Email: rammanoharp@gmail.com
} 

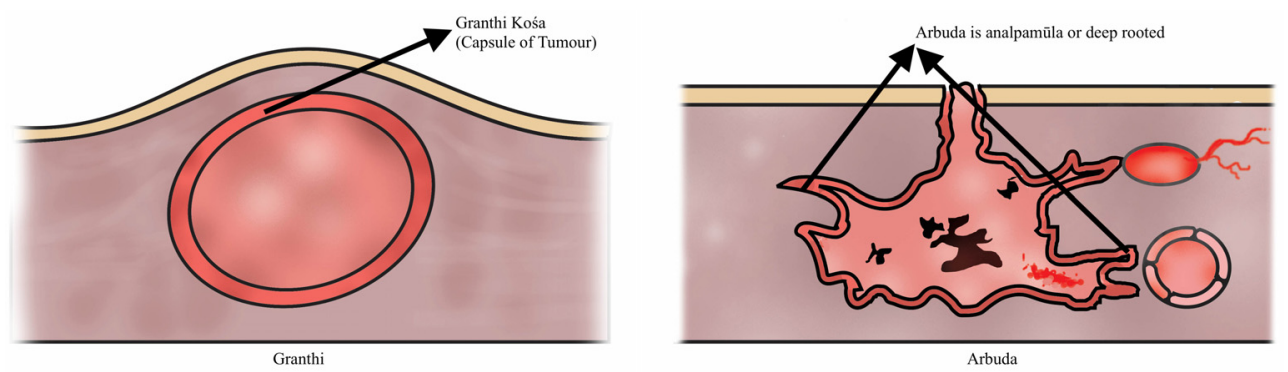

Fig. 1. Pictorial differentiation of Granthi and Arbuda as described in classical texts of Ayurveda

part of the name for cancer specialists oncologists.

The American Cancer Society describes the early history of cancer and acknowledges that Egyptians and the Greeks knew about the disease. The modern understanding of cancer and the development of Oncology as a medical specialty can be traced to the Greeks and in particular Hippocrates. Curiously enough, there is no mention of any contributions from the other great medical traditions of the world, especially Ayurveda and Chinese Medicine.

This paper attempts to explore the descriptions of cancer in the classical Ayurvedic texts and to construct the development of this knowledge in the course of the evolution of the tradition of Ayurveda.

\section{Descriptions of diseases that Resemble Cancer in the Classical Ayurvedic texts}

A cursory look at classical Ayurvedic literature gives ample indication that cancer was known to ancient Ayurvedic physicians. Definitely, cancer is not a modern disease. It is an interesting exercise to explore how much the ancient Ayurvedic physicians knew about cancer.

The most obvious term in the texts that correlates with cancer is arbuda. Arbuda cannot be explained without referring to a related term granthi. Both of these terms refer to swelling or growths that are hard on touch and do not easily go away. In fact, they tend to grow bigger over a period of time. Together, the terms arbuda and granthi seems to represent tumour forming pathologies that have been described in the earliest text books of Ayurveda.

Granthi is a growth, a swelling with a knotted appearance ${ }^{1}$. On the other hand, arbuda is a more dangerous type of growth that can hurt or kill the individual ${ }^{2}$ and that which can grow in size by multiples of hundreds and crores $^{3}$.

There are descriptions of the above mentioned diseases in the Caraka Samhitā and the Suśruta Samhitā, which represent the medical and surgical schools in Ayurveda.

Caraka mentions these diseases under the group of diseases that are characterized by swelling or śopha (Trikamji, 2013, p.107). Suśruta describes arbuda and granthi as diseases that need surgical management (Trikamji \& Narayan, 2008, pp. 471-475).

The observations in the texts differentiating between granthi and arbuda are very interesting. Caraka distinguishes granthi from arbuda by the presence of a capsule ${ }^{4}$ (Trikamji, 2013, p. 489). In other words, granthi is encapsulated while arbuda is not. When a granthi is surgically removed, Caraka emphasises

\footnotetext{
1 The term granthi means knotted - grathanād granthih

2 The word arbuda is derived from the root arv himsāyam, meaning that which hurts or kills.

${ }^{3}$ Arbuda also denotes a count of hundreds and crores - arbudo śatakotisu.

${ }^{4}$ Caraka mentions that a granthi is encapsulated having a kośa.
} 


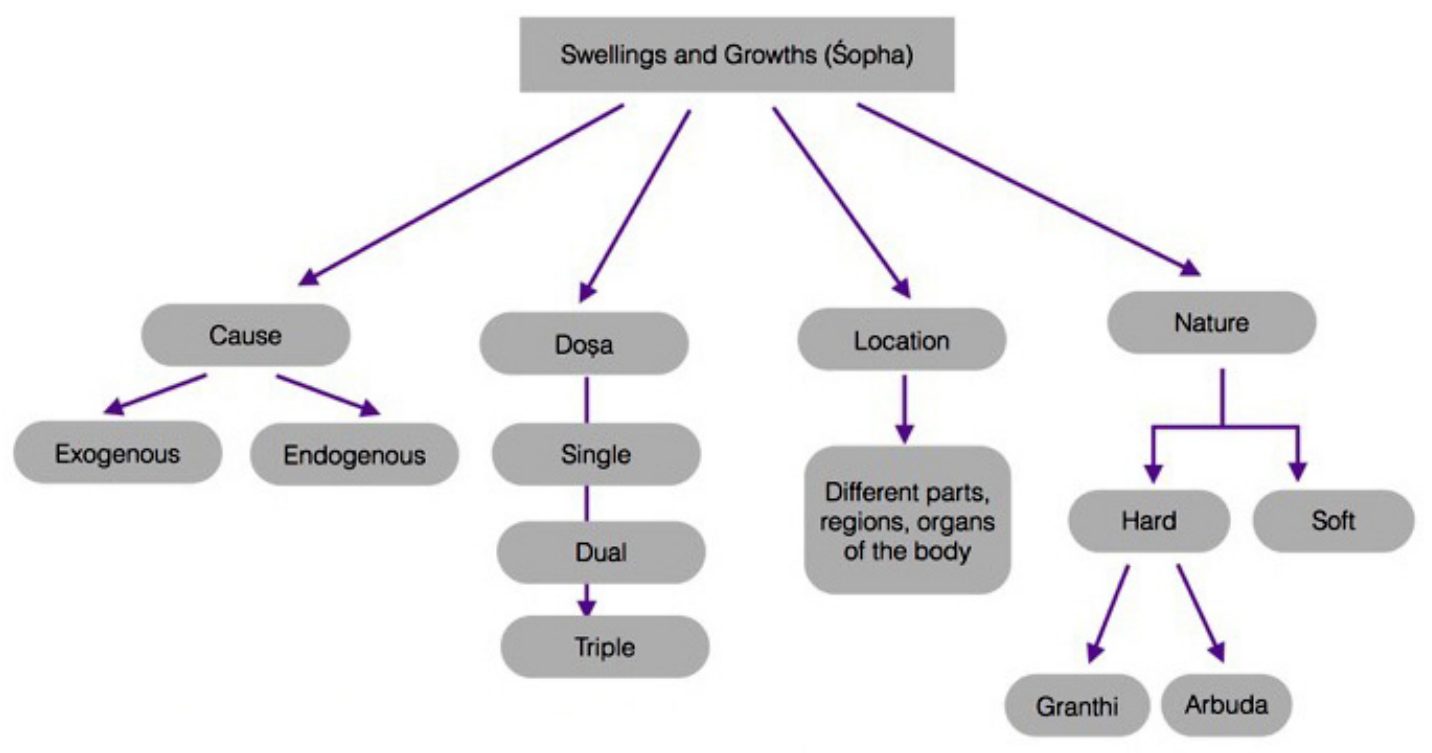

Fig. 2: From Caraka Saṃhitā, Sūtrasthāna, 18th Chapter - Triśothīya

that it should be removed along with the capsule to prevent recurrence ${ }^{5}$ (Trikamji 2013, p. 489).

Suśruta describes arbuda as a slowly progressing growth ${ }^{6}$ (Trikamji \& Narayan, 2008, p. 312), which can then take on a rapid course when it begins to ulcerate and spread $^{7}$ (Trikamji \& Narayan, 2008 p. 313). Because of the predominant involvement of kapha (Trikamji \& Narayan, 2008 p. 313), the disease is silent and slow in the initial phase.

Suśruta specifies that even in the beginning stage, there is more to arbuda than meets the eye. Arbuda has deep roots (analpamulamm). As it progresses, it can consolidate itself locally over a large area (krtamūlam ) and become fixed (acālyam), which indicates a bad prognosis (Trikamji \& Narayan, 2008 pp. 312, 313).

An arbuda is especially difficult to manage if it manifests in a vital organ (marma) or a vital channel (srotas). An arbuda can recur on the same site again even after treatment (adhyarbuda) or manifest in another location (dvirarbuda).

The $d$ virarbuda can occur simultaneously (yugapad) or in due course (cirādvā). Dvirarbuda seems to be a very early reference to metastasis of cancers in the Ayurvedic tradition ${ }^{8}$ (Trikamji \& Narayan, 2008, p.313).

\footnotetext{
${ }^{5}$ Interestingly, the Caraka Samhitā recommends removal of the capsule along with the granthi or tumour. vipätya coddhrtya bhișak sakośam śastreṇa dagdhvā vranavaccikitset. Not only that, Caraka also warns that if the tumour is not completely excised, it will grow again slowly - adagdha ịsat pariśeșitaśca prayāti bhūyo/pi śanairvivrddhim, tasmādaśeșạ kuśalaih samantācchedyo bhavedvīksya śarīradeśān

${ }^{6}$ Suśruta gives vivid descriptions of the development of malignant growths - gātrapradeśe kvacideva doșāh sammūrchitāh māmsamabhipradūṣya, vṛttam sthiram mandarujạ̣ mahāntamanalpamūlam ciravrddhyapākaṃ, kurvanti māmsopacayạ̣ tu sopham tamarbudạ̣ śästravido vadanti - Arbuda can manifest in any part of the body, it is not very painful, but can be huge and widespread. It grows slowly and does not suppurate for a long time.

7 Suśruta points out that the arbuda that ulcerates and oozes cannot be treated. So also that which is growing in a vital organ or major channels and those that are immovable - samprasrutam marmani yacca jātam, srotassu vā yacca bhavedacālyam

${ }^{8}$ The recurrence of arbuda at the same site of the previous growth or its simultaneous or later occurence at another location have been explicitly mentioned by Suśruta indicating that he was aware of the recurrence and metastasis of malignant tumours yajjāyate/nyat khalu pūrvajāte jñeyam tadadhyarbudamarbudajñaih, yaddvandvajātam, yugapat kramādvā dvirarbudam tacca bhavedasādhyam. Dvirarbuda is specifically mentioned as incurable.
} 
Adhyarbuda obviously refers to relapse of the cancer at the same site. According to Suśruta, if an arbuda is not removed completely through a surgical procedure, it will recur again quickly in a very aggressive manner and kill the person like fire $^{9}$ (Trikamji \& Narayan, 2008, p. 474).

Arbuda is classified in Ayurveda in two ways - on the basis of the predominant dosa and also on the basis of the dhatu involved. Thus, we have vātārbuda, pittārbuda and kaphārbuda as well as māmsārbuda and medorbuda (Trikamji \& Narayan, 2008 pp. 312, 313).

From the above discussion, we can understand that the ancient Ayurvedic texts give a fairly clear description of the tumor forming cancers, differentiating between benign and malignant tumors and also highlighting the stage wise progression of cancer.

\section{The stages in the development of}

\section{ARBUDA AND ITS CORRELATION WITH CANCER}

The following points emerge from the descriptions of arbuda in the classical texts of Ayurveda.

1. Arbuda is a localized growth in any part of the body - gātrapradesie kvacideva doṣāh

2. Initially it grows slowly and silently ciravrddhi, apāka

3. Local spreading of the growth and rooting analpamūlạ̣

4. Fixation - krtamūlatvam, aclyām

5. Spreading - mahāvāstuparigraha

6. Ulcerating - samprasrutam

7. Recurrence - adhyarbuda

8. Metastasis - dvirarbuda
There are indications that we get from the texts that arbuda is a secondary outcome of a chronic inflammatory pathology. Broadly speaking arbuda and granthi come under the category of diseases grouped under the heading sopha. Sopha can be loosely translated as inflammation, swelling. This is perhaps an indication that sopha especially when it persists in chronic form predisposes the individual to develop arbuda. In the context of the treatment of vātarakta, a chronic inflammatory disease affecting the joints of the body, it has been mentioned that arbuda can manifest as a complication (Sastri, 2012) ${ }^{10}$.

To summarize, what we learn from the Ayurvedic description of arbuda is that the tumour forming cancers are later developments in the evolution of disease, hinting at the possibility of a pre-cancer state.

\section{Other diseases Similar to CANCER DESCRIBED IN THE AYURVEDIC TEXTS}

It is not very clear whether the ancient Ayurvedic physicians were aware of the nontumour forming cancers. For that matter, it seems that Ayurveda did not group all cancers under a single heading. For instance, certain stages of diseases like gulma, pāndu and vidradhi seem to resemble cancer. There is an opinion amongst Ayurvedic physicians that the cancers of the blood correlate with some presentations of pāndu. It is not easy to judge on the basis of textual descriptions whether the above mentioned diseases relate to cancer in the way it is understood today (Kumaraswamy, 1994, pp. 218-31).

There is a disease known as valmīka described in the later texts of Ayurveda that seems

\footnotetext{
${ }^{9}$ According to Suśruta, an incompletely removed arbuda can recur again - saśesadoșāni hi yo/rbudāni karoti tasyāśu punarbhavanti, tasmādaśeșāni samuddharettu hanyuh saśeșạni yathā hi vahnih - While arbuda is generally considered to develop and grow slowly, the relapsed arbuda is observed to grow very fast and kills the patient like fire.

${ }^{10}$ Vătarakta caused by derangement of all the three doșas, which also leads to development of arbuda is to be discarded - tridoșajam tyajed srāvi stabdhamarbudakāri yat.
} 
to match the description of cancer (Sastri, 2012). In the Siddha system of medicine, this is known as Puttru, which means the same as valmika. Siddha physicians equate cancer with Puttru Noi. However, conditions like gulma, pāndu, vidradhi and valmīka cannot be definitely correlated with cancer.

The study of arbuda seems to have been a specialized engagement for the physicians of Ayurveda. Suśruta mentions a term arbudajña, which means those who were having specialized knowledge about arbuda. This is akin to the modern term oncologist (Trikamji \& Narayan, 2008, p. 313).

\section{The Treatment of Granthi}

We shall now discuss about the treatments described in Ayurveda for arbuda and granthi, considering the fact that these conditions resemble cancer the most as we understand it today.

When the patient has the strength, purificatory therapies like emesis, purgation, and nasal purgation are indicated for all types of granthis (tumours). Specifically in vāta type of granthi, medication with the four unctuous substances, application of paste externally and various types of fomentations are recommended. When these measures fail, blood letting is indicated. The aim of these treatments is to cause lysis or suppuration of the swelling after which it is to be incised and drained (Trikamji \& Narayan, 2008 p. 470). In Pitta type of granthi, leech application is recommended followed by purgation. When the swelling is ripened, it is to be incised and drained (Trikamji \& Narayan, 2008, pp. 470-471). In the kapha type of granthi, internal purification is to be done and then fomentation of the swelling should be done. Powder of herbs should then be applied externally as paste. If the swelling does not become ripe after these measures, it should be excised surgically and cauterized. Care must be taken to ensure that there is no residue left. Remnants of the granthi can grow again to form fresh tumours. The treatment for granthi caused by māmsa and medas are more or less the same. In granthi caused by medas, the swelling has to be smeared with paste of sesame seeds heated with an iron plate by placing cloth folded twice above the swelling. It should be massaged before excision and cauterization (Trikamji \& Narayan, 2008 p. 471).

Interestingly siragranthi, which seems to resemble varicose veins rather than a real tumour is also discussed along with other granthis (Sastri, 2012).

As mentioned earlier, the Caraka Samhitā, points out that granthi or tumour is enclosed within a capsule and that the capsule must be excised along with the tumour. However, there is no reference to adhyarbuda (relapse of tumour) and dvirarbuda (simultaneous or consequent occurrence of tumour - metastasis) in the Caraka Samhitā.

The ancient physicians and surgeons found it difficult to distinguish between granthi and arbuda. In one context, it is mentioned that there is no difference between granthi and arbuda and that the line of treatment is not so different ${ }^{11}$. Even a granthi may become immovable and then it is incurable. Nevertheless, these two conditions have been described distinctly. One difference is that while granthi can recur if not completely removed, the arbuda that recurs is said to kill the patient like fire.

\section{The treatment of Arbuda}

In the case of arbuda, treatment similar to granthi is recommended. However, there is a greater emphasis on fomentation and blood letting

\footnotetext{
${ }^{11}$ Caraka says that there is not a significant difference in the occurrence, cause, appearance, doșa and dūsya between granthi and arbuda. Therefore the line of treatment is also very similar - granthyarbudānām ca yato/viśeșah pradeśahetvākrtidoșadūsyaih tataścikitsedbhiṣagarbudāni vidhānavidgranthicikitsitena
} 
in arbuda caused by vāta. Poultice, steam from a pipe and purgation are recommended. In arbuda caused by pitta, mild fomentation is recommended as well as external application of herbal pastes.

In arbuda caused by kapha, complete purification of the body is recommended including blood letting. The medications used for emesis and purgation are to be applied externally. In the treatment of arbuda caused by kapha, it is advised to smear the swelling with herbs and meat to attract flies that will eat away the growth of the arbuda. The remnants of the arbuda after the flies have eaten it can be scraped away and cauterized and then the wound may be healed with appropriate medicines. The use of strong alkalies repeatedly is recommended for the management of arbuda caused by kapha (Trikamji \&Narayan, 2008 p. 470).

The arbuda caused by medas has to be fomented and then opened. After the fat has been removed and the bleeding has stopped, the wound should be sutured. Herbal paste may be applied thereafter.

In the case of arbuda, the texts warn that incomplete removal of an arbuda can result in recurrence of the growth very soon. Therefore, the arbuda has to be completely removed with the help of alkali, surgery or cautery.

\section{The Clinical UNDERSTANDING OF BENIGN and malignant tumours in Ayurveda}

The above discussions indicate that Ayurveda recognized the clinical manifestations of benign and malignant tumours. The approach to treatment of tumours in Ayurveda seems to aim at its lysis by the application of pastes and fomentation externally in addition to blood letting. Ultimately, surgical intervention and cauterization are recommended because it was recognised that residual tumours can grow again.

In the management of arbuda caused by $k a p h a$, an interesting treatment has been described that resembles maggot therapy. The smearing of meat with herbal paste on the swelling to attract flies is said to bring about debridement of the wound and stimulate the healing just like maggot therapy.

At least in principle, the emphasis on alkalis, cautery and surgery echoes the modern approach to cancer management with chemotherapy, radiation and surgery.

\section{Application of Ayurveda in the Management of Cancer in Modern times}

Anecdotal accounts abound reporting success stories of cancer being managed by Ayurvedic physicians. However these claims are not backed by rigorous scientific research. Claims of success range from complete cure to improvement of quality of life and better outcomes during radiation and chemotherapy.

Some reports of success go beyond mere anecdotes. A French oncologist traveled to India in 2013 with one of his former patients to try and understand how traditional Indian medicine (known as Ayurveda) cured her cancer. The whole story has been portrayed in the documentary called the "Indian Summer". The film follows the journey of a surprising and unusual couple: a world famous French oncologist, both intrigued and questioning, who has the desire to discover other medical approaches and to question his own knowledge and one of his former patients, a patient who chose traditional Indian medicine instead of following his recommended treatment and who joins him in retracing her personal path against cancer that had a happy ending.

After undergoing treatments by Ayurvedic practitioners in India for three years, and returning to France cancer free, she looks up a leading oncologist, Dr. Thomas Tursz, who had scoffed at her decision to try Ayurvedic medicine prior to going to India, and challenges him to meet the doctors who treated her there (Brook, 2014). 
An article reports in the Journal Integrative Cancer Therapies that Asian botanicals (from both Chinese and Ayurvedic medicine) are being evaluated for their ability to improve therapeutic gain through the modulation of reactive oxygen species. An increase in the efficacy of radiotherapy on tumor tissue allows a reduction in the dose applied to normal tissues. In addition, some botanicals may selectively protect normal tissue or increase its repair following radiation therapy. The results are promising enough to consider clinical trials (Sagar, 2013 pp 5-10). In response to this paper, Biran Lawenda from Uniformed University of Health Sciences, Bethesda points out that numerous botanical agents, many of which are used in whole medical system practices (i.e. traditional Chinese medicine, Ayurvedic medicine, etc.), have been shown to exhibit radiomodifying effects on tumors and normal tissues in-vitro and in-vivo studies. Some of these agents can enhance the therapeutic gain of radiation therapy by either acting as a radiosensitizer to tumor cells and/or as a radioprotector to normal cells. Botanical agents are comprised of multiple phytochemical compounds that may work individually or synergistically to not only improve radiation therapy outcomes, but may also exhibit a variety of anti-cancer effects as well. It will be important to evaluate these botanicals for efficacy, tumor specificity, and safety profiles before they can be recommended during radiation therapy. Metri et al. also makes similar recommendations to supplement radiation and chemotherapy with Ayurvedic medications (Metri, 2013, pp.115-29).

Prakash (2011, pp. 56-59) has reported the completion of 12 years of disease free survival with Ayurvedic treatment of a 16 year old boy who was diagnosed with acute myeloid leukaemia with bone marrow pathology showing $85 \%$ blasts in February 07, 1997. He received two cycles of induction chemotherapy $(3+7$ protocol) with daunomycin and cytosar, following which he achieved incomplete remission with bone marrow aspirate showing $14 \%$ blasts. Subsequently, the patient received two cycles of high-dose cytosine arabinoside Ara-C and achieved remission. However, his disease relapsed on August 29, 1997. Peripheral blood smear showed $6 \%$ blast cells and bone marrow showed $40 \%$ blast cells. The patient refused further chemotherapy and/or bone marrow transplant and volunteered for Ayurvedic therapy (AYT) advocated by the author from September 09, 1997. Bone marrow studies done after six months of AYT indicated that the disease was in remission. The AYT was continued for five years and stopped (Prakash, 2011, pp.56-9).

Rastogi reported favourable outcomes with Ayurvedic treatment in metastatic liver disease. A diagnosed patient with metastatic liver disease that included abnormal liver functions and symptomatic presentation was treated with Ayurvedic therapies and was observed for 10 days for any possible changes. A substantial clinical and biochemical improvement was observed in this patient after 10 days of treatment. This improvement was noted to be consistent at a 1week follow-up after the patient was discharged from the hospital (Rastogi, 2011, pp.719-22).

\section{Modern research on Ayurveda AND CANCER}

Modern research is being conducted to explore the anti-cancer effects of herbs and formulations described in classical texts and used by Ayurvedic physicians in clinical practice. Plumbago rosea, Withania somnifera, Semecarpus anacardium, Achyranthes aspera, Saraca asoka, Hemidesmus indicus, Pandanus odoratissimus, Curcuma longa, Tinospora cordifolia, Commiphora mukul and the list goes on. Varanadi Ghritam and Indukantam Ghritam are formulations that have been explored for their beneficial effects in cancer (Aggarwal, 2006, pp. 87-116; Chang, 2003 pp. 541-3; Vayalil, 2002, 787-96). The traditions of text and practice in Ayurveda continue to be explored for new leads 
to develop drugs for management of cancer (Kumaraswamy, 1994, pp. 218-31). Vincristine and Vinblastine were harvested from the plant Vinca rosea for the management of leukemia. This plant does not, however, figure prominently in the classical Ayurvedic texts. The numerous medicinal plants mentioned in Ayurvedic literature have shown potential benefits in the management of cancer, but the preliminary findings have not been translated into potent medicines that can be effectively used at the point of care.

\section{Conclusions}

A review of classical Ayurvedic literature reveals that the clinical features of tumour forming cancers were well understood in the very early stages of the evolutionary history of Ayurveda. Strikingly, the benign and malignant tumours have been distinguished with Caraka pointing out the presence of a capsule in the case of benign tumours called granthi while all the authorities point out the fixation, rooting and spreading of the malignant type of tumour known as arbuda. Suśruta clearly describes the various stages in the development of malignant tumours and also recognizes recurrence as well as metastasis. Especially, he points out the need to remove the traces of the tumour completely to avoid the risk of a recurrence that can be fatal like a raging fire. In terms of treatment, Ayurveda recommends internal purification, external treatments like application of paste, fomentation and blood letting to induce lysis of the tumour. Ultimately large tumours have to be excised and the remnants removed completely by application of alkali or cautery. In arbuda caused by cancer, a procedure very similar to maggot therapy has been described. Conditions resembling cancer can be found in the description of other diseases also indicating that cancerous states may develop from pre-existing conditions but there is no evidence of any attempt to classify all these conditions under one umbrella term. On the other hand, non-cancerous conditions like varicose veins have been described along with other tumours (granthi). Certain stages of the disease Pạndu resemble leukaemia, but this is mostly an inference of modern scholars of Ayurveda and there is no evidence that the texts reveal an understanding of non-tumour forming cancers. Also the histological differentiation of different types of cancers were obviously unknown to the Ayurvedic physicians. Interestingly, cancer is described to be an outcome of śopha or inflammation hinting upon the notion that chronic inflammation can lead to the development of cancer. In spite of the lack of rigorous evidence anecdotal accounts of success abound in the application of Ayurvedic treatment for management of cancer. Albeit scanty, some studies lend support to the possibility that Ayurvedic treatments can lead to beneficial outcomes in cancer patients. Systematic and rigorous research is needed to pinpoint the specific benefits that Ayurveda can offer in the management of cancer.

\section{BIBLIOGRAPHY}

Aggarwal, B.B., Ichikawa, H., Garodia, P., Weerasinghe, P., Sethi, G., Bhatt, I.D., Pandey, M.K., Shishodia S. and Nair, M.G. From traditional Ayurvedic medicine to modern medicine: identification of therapeutic targets for suppression of inflammation and cancer, Expert Opin Ther Targets, 10.1, Feb (2006): 87118.

Chang, R. and White, J.D. Asian therapies for cancercoming of age, J Altern Complement Med., 8.5, Oct (2002): 541-3.

http://www.cultureunplugged.com/documentary/watchonline/play/51715/Indian-Summer (Abbrev. Brook) last accessed on 2 April 2015.

Kumaraswamy, B.V. Ayurvedic identification and conceptual analysis of cancer, Anc Sci Life, 13.3-4, Jan (1994): 218-31.

Metri, K., Bhargav, H., Chowdhury, P. and Koka, P.S. Ayurveda for chemo-radiotherapy induced side effects in cancer patients, J Stem Cells. 8.2 (2013): 115-29.

Prakash, B. Treatment of relapsed undifferentiated acute myeloid leukemia (AML-M0) with Ayurvedic therapy, Int J Ayurveda Res., 2.1, Jan (2011): 56-9. 
Prasad, G.C., Sahu, M. and Deshpande, P.J. Concept of cancer in Ayurveda, Anc Sci Life 1.3, Jan(1982): 1726.

Rastogi, S. and Rastogi, R. Ayurvedic intervention in metastatic liver disease, J Altern Complement Med, 18.7, Jul(2012): 719-22.

Sagar, S.M. Can the therapeutic gain of radiotherapy be increased by concurrent administration of Asian botanicals?, Integr Cancer Ther, 9.1, Mar(2010): 513.

Sastri, Brahmashankara (Tr.). Mādhavanidāna of Mādhavakara (Abbrev: Mādhava) with ancient Sanskrit Commentaries, Chaukhambha Sanskrit Sansthan, Varanasi, 2012.

Sastri, Hari Sadashiva (Ed). Aștāingahrdaya of Vāgbhața (Abbrev: A.Hrdaya) with an ancient Sanskrit Commentary, Chaukhambha Sanskrit Series Office, Varanasi, 2012.

Sharma, Shivaprasad (Ed). Așțāngasangraha of Vāgbhața (Abbrev: A.Sangraha) with an ancient Sanskrit Commentary, Chaukhambha Sanskrit Series Office, Varanasi, 2012.
Singh, R.H. An assessment of the ayurvedic concept of cancer and a new paradigm of anticancer treatment in Ayurveda, J Altern Complement Med., 8.5, Oct (2002): 609-14.

Singhal, G.D. Cancer in ancient Indian surgery, Anc Sci Life, 2.3, Jan (1983): 137-40.

Suraiya, J.N. Medicine in ancient India with special reference to cancer, Indian J Cancer, 10.4, Dec (1973): 391-402.

Trawick, M. An Ayurvedic theory of cancer, Med Anthropol, 13.1-2(1991): 121-36.

Trikamji, Yadavji and Narayan, Ram (Ed). Suśruta Samhitā of Suśruta (Abbrev: Suśruta) with an ancient Sanskrit Commentary, Chaukhambha Surbharathi Prakashan, Varanasi, 2008.

Trikamji, Yadavji (Ed). Caraka Samhitā of Caraka (Abbrev: Caraka) with an ancient Sanskrit Commentary, Chaukhambha Prakasan, Varanasi, 2013.

Vayalil P.K., Kuttan G. and Kuttan R. Protective effects of Rasāyanās on cyclophosphamide- and radiationinduced damage, J Altern Complement Med., 8.6, $\operatorname{Dec}(2002)$ : 787-96. 